\title{
ETHNOBOTANICAL STUDY OF MEDICINAL PLANTS USED BY THE JAH HUT PEOPLES IN MALAYSIA
}

\author{
K. W. LIN
}

\section{ABSTRACT}

CONTEXT: An ethnobotanical study was carried out among the Jah Hut people who live in the central part of peninsular Malaysia. MATERIALS AND METHODS: The information on the medicinal plants was obtained from interview with a traditional medicinal man. The traditional uses and remedies were documented. The literature searches were carried out for the evaluation on the current status of investigations on these plants. RESULTS: In this study, we present 16 species of plants, which are commonly used among the Jah Hut people to cure some common diseases. DISCUSSIONS: This study is important to preserve the knowledge of medicinal plants used by Jah Hut people. The surveys of phytopharmacological literatures of these plants have great pharmacological and ethnobotanical significance.

KEY WORDS: Ethnobotany, herbs, Jah Hut, Malaysia, medicinal plants

The area of ethnobotanical study is located in Pahang state, the central part of peninsular Malaysia. This study was carried out amongst small ethnic group of 'Orang Asli' (aboriginal peoples), Jah Hut, who live in Kampung Keboi ('Kampung' means village), within the tropical forest in Jerantut district. The climate is equatorial with an average temperature of 23$32^{\circ} \mathrm{C}$. The annual rainfall is between 1525 and $3050 \mathrm{~mm} /$ year. These climate conditions allow the growth of diverse plants with economical value and many of which are therapeutically important. There are about 1300 medicinal plant products registered by the Ministry of Health of Malaysia and are available in market. ${ }^{[1]}$

There are approximately 4000 Jah Hut peoples

Lviv National Medical University, Lviv, Ukraine Correspondence: distributed over 11 villages, which extend along the west bank of Pahang River from Jerantut in the north to Termeloh in the south. They speak the Jah Hut language, which is affiliated to the Mon-Khmer branch of Austroasiatic family. It does assimilate with many Malay words. In Jah Hut language, 'Jah' means 'people' and 'Hut' means 'no', however they cannot explain the meaning of these combined words. Kampung Keboi is one of the smallest Jah Hut settlements and has about 100 inhabitants. Jah Hut people live in Malay style houses, which stand on stilts. Their main agricultural activities include rubber tapping, growing rice, and rearing domestic fowls, such as chicken. The wood carving activities are practiced among the Jah Hut. This is not the only source of income, but also an extension

K. W. Lin, Lviv National Medical University, 69 Pekarska Street, 79010 Lviv, Ukraine. E-mail: lin_kahwai@yahoo.com 
of their traditional ideological framework based on their religious beliefs. Although they live in forests, they are not complete isolated, their economical dealing with neighboring people exist since a few 100 years ago. ${ }^{[2]}$

The traditional herbal knowledge is passed from generation to generation in the verbal form by traditional medicinal man or 'bomoh'. In recent years, folk medicine is no more an attraction to the younger generation, they are more dependent on western medicine. They are unable to recognize the herbs and possess very little knowledge on traditional herbal remedy. Nowadays many young people migrate to urban areas for education and job opportunities. As a consequence, only the elder people possess the knowledge of herbs and it is estimated only a handful of people are able to use the traditional remedy to treat illness. Thus, the traditional knowledge is rapidly eroding. In addition, there is a lack of ethnobotanical survey carried out in these areas. For these reasons, the documentations of the traditional uses of indigenous plants are important to preserve their knowledge. The purpose of this study is to investigate the traditional uses and remedies of various indigenous plants, which are commonly used among the Jah Hut people.

\section{MATERIALS AND METHODS}

All verbal information on the medicinal plants were obtained through an interview with a traditional medicinal man. This was done by Rev. Anthony Naden, a priest of a Catholic Church, who devoted his life in the service of the aboriginal people. The local name, parts of plants used, ailments treated, preparations and mode of uses were recorded. The collected specimens were identified at the species leve in the Herbarium of Forest Research Institute Malaysia under supervision of Dr. E. Soepadmo. The voucher specimens were dried, labeled and stored. The search of recent scientific phytopharmacological literatures were carried out in order to obtain the information on the current status of investigations of these plants.

\section{RESULTS}

In this study, 16 species of plants were documented. The information obtained includes the botanical name, local name, parts of the plant used, traditional uses, preparations and modes of uses. The data recorded in Table 1 are arranged in alphabetical order according to botanical names.

It is worth to note that some of these plants have already been studied experimentally, i.e. Eurycoma longifolia, Hedyotis capitellata, Melastoma malabathricum, Morinda citrifolia, Lycopodiella cernua and Vernonia cinerea. The pharmacological activities reported in recent literatures are recorded in Table 2.

\section{DISCUSSIONS}

Eurycoma longifolia are extensively studied in some institutions in Malaysia and the herbal preparations are available in the market. ${ }^{[3-12]}$ It is a popular herb used by many local races of Malaysia and mainly used as aphrodisiac, antipyretic and anti-malarial remedy. ${ }^{[39]}$ Not surprisingly, Jah Hut people often use it as an aphrodisiac remedy. This observation agrees with various pharmacological studies in which

\section{Table 1: Remedies of plant used by Jah Hut peoples}

\begin{tabular}{|c|c|c|c|c|c|}
\hline $\begin{array}{l}\text { Sr. Botanical name } \\
\text { No. (family name) }\end{array}$ & $\begin{array}{l}\text { Local } \\
\text { names }\end{array}$ & $\begin{array}{l}\text { Parts } \\
\text { used }\end{array}$ & $\begin{array}{l}\text { Traditional } \\
\text { uses }\end{array}$ & Preparations & Modes of uses \\
\hline $\begin{array}{l}\text { 1. A. angustiloba (L.) } \\
\text { Miq. (Apocynaceae) }\end{array}$ & Ludoh & Leaves & Headache & Crushed & $\begin{array}{l}\text { External application } \\
\text { (two to three times } \\
\text { daily) }\end{array}$ \\
\hline $\begin{array}{l}\text { 2. Coptosapelta tomentosa (L.) } \\
\text { (Blume) Valeton ex K. Heyne } \\
\text { (Rubiaceae) }\end{array}$ & Salah & Roots & $\begin{array}{l}\text { Parasitic worm } \\
\text { infections }\end{array}$ & Decoction & $\begin{array}{l}\text { Oral (one glass two } \\
\text { to three times daily) }\end{array}$ \\
\hline $\begin{array}{l}\text { 3. Eurycoma longifolia (L.) } \\
\text { Jack (Simaroubaceae) }\end{array}$ & Tongkat Ali & Roots & Virility & Decoction & $\begin{array}{l}\text { Oral (two } \\
\text { teaspoons daily) }\end{array}$ \\
\hline $\begin{array}{l}\text { 4edyotis capitellata (L.) Wall. } \\
\text { ex G. Don (Rubiaceae) }\end{array}$ & Bubut & Roots & $\begin{array}{l}\text { Urinary } \\
\text { problems }\end{array}$ & Decoction & $\begin{array}{l}\text { Oral (two to three } \\
\text { times daily) }\end{array}$ \\
\hline $\begin{array}{l}\text { 5. H. populneus (L.) (Geisl.) } \\
\text { Pax (Euphorbiaceae) }\end{array}$ & Remaya & Leaves & Headache & Crushed & $\begin{array}{l}\text { External application } \\
\text { (two to four times } \\
\text { daily) }\end{array}$ \\
\hline $\begin{array}{l}\text { 6. Lycopodiella cernua (L.) } \\
\text { Pic. Serm. (Lycopodiaceae) }\end{array}$ & Paku & Leaves & Vertigo & $\begin{array}{l}\text { Crushed with } \\
\text { charcoal }\end{array}$ & $\begin{array}{l}\text { External application } \\
\text { on face (two to } \\
\text { three times daily) }\end{array}$ \\
\hline $\begin{array}{l}\text { 7. Lygodium flexuosum (L.) } \\
\text { Sw. (Schizaeaceae) }\end{array}$ & Ribu & Leaves & Measles & $\begin{array}{l}\text { Crushed with } \\
\text { rice }\end{array}$ & $\begin{array}{l}\text { External application } \\
\text { (two to four times } \\
\text { daily) }\end{array}$ \\
\hline $\begin{array}{l}\text { 8. Melastoma malabathricum } \\
\text { (L.) (Melastomataceae) }\end{array}$ & Senuduk & Roots & Diarrhea & Decoction & $\begin{array}{l}\text { Oral (one glass two } \\
\text { to three times daily) }\end{array}$ \\
\hline $\begin{array}{l}\text { 9. Maranta arundinacea } \\
\text { (L.) (Marantaceae) }\end{array}$ & Ketap & Roots & $\begin{array}{l}\text { Burning feeling } \\
\text { in stomach } \\
\text { after delivery }\end{array}$ & Decoction & $\begin{array}{l}\text { Oral (one glass two } \\
\text { to three times daily) }\end{array}$ \\
\hline $\begin{array}{l}\text { 10. Morinda citrifolia (L.) } \\
\text { (Rubiaceae) }\end{array}$ & Mengkudu & $\begin{array}{l}\text { Leaves, } \\
\text { fruits }\end{array}$ & Boils on head & $\begin{array}{l}\text { Decoction } \\
\text { (leaves, fruits) } \\
\text { /crushed (fruits) }\end{array}$ & $\begin{array}{l}\text { External application } \\
\text { (two to three times } \\
\text { daily) }\end{array}$ \\
\hline $\begin{array}{l}\text { 11. P. minima (L.) } \\
\text { (Solanaceae) }\end{array}$ & Lepung & $\begin{array}{l}\text { Leaves, } \\
\text { roots }\end{array}$ & $\begin{array}{l}\text { Pain below } \\
\text { naval }\end{array}$ & Decoction & $\begin{array}{l}\text { Oral (one glass four } \\
\text { to five times daily) }\end{array}$ \\
\hline $\begin{array}{l}\text { 12. Pseuderanthemum } \\
\text { crenulatum (L.) (Lindl.) } \\
\text { Radlk. (Acanthaceae) }\end{array}$ & Seemelet & Leaves & Boil on body & Crushed & $\begin{array}{l}\text { External application } \\
\text { (two to four times } \\
\text { daily) }\end{array}$ \\
\hline $\begin{array}{l}\text { 13. P. piloselloides (L.) } \\
\text { M.G. Price (Polypodiaceae) }\end{array}$ & Titik & Leaves & Pain on body & $\begin{array}{l}\text { Crushed/ } \\
\text { decoction }\end{array}$ & $\begin{array}{l}\text { For crush, external } \\
\text { application/for } \\
\text { decoction, oral (one } \\
\text { glass two to three } \\
\text { times daily) }\end{array}$ \\
\hline $\begin{array}{l}\text { 14. Smilax lanceifolia (L.) } \\
\text { Roxb. (Smilacaceae) }\end{array}$ & Dunnon & Leaves & Pricking pain & Crushed & External application \\
\hline $\begin{array}{l}\text { 15. Smilax myosotiflora (L.) } \\
\text { (Smilacaceae) }\end{array}$ & Ubi Jaga & Bulbs & $\begin{array}{l}\text { Virility, back } \\
\text { pain }\end{array}$ & Decoction & Oral \\
\hline $\begin{array}{l}\text { 16. Vernonia cinerea (L.) } \\
\text { Less. (Compositae) }\end{array}$ & Trombe & $\begin{array}{l}\text { Leaves, } \\
\text { roots }\end{array}$ & Asthma & Decoction & $\begin{array}{l}\text { Oral (one glass two } \\
\text { to three times daily) }\end{array}$ \\
\hline
\end{tabular}

anti-hyperglycemic, anti-malarial, antiproliferative, anti-schistosomal, anxiolytic and aphrodisiac activities are found in both in vivo and in vitro studies. ${ }^{[3-17]}$

boils by topical application of leaves or fruits This coincides with pharmacological validation, since boils (impetigo, folliculitis, furuncles, or carbuncles) are often caused by Staphylococcus aureus; $M$. citrifolia possess Jah Hut people often use $M$. citrifolia to treat anti-bacterial properties to counter it. ${ }^{[30]}$ 
Table 2: Pharmacological activity of plants reported in literatures

\begin{tabular}{llll}
\hline & Plants & Pharmacological activity reported in literatures & References \\
\hline 1. & Eurycoma longifolia & Anti-hyperglycemic, anti-malarial, anti-proliferative, & $3-17$ \\
2. & Hedyotis capitellata & Anti-schistosomal, anxiolytic, aphrodisiac & 18 \\
3. & Lycopodiella cernua & Anti-bacterial & 18,19 \\
4. & Melastoma malabathricum & Anti-bacterial, anti-nociceptive, anti-proliferative, anti-viral & $18,20,21$ \\
5. & Morinda citrifolia & $\begin{array}{l}\text { Analgesic, anti-atherosclerotic, anti-bacterial, anti-fungal, } \\
\text { anti-helmintic, anti-hypertensive, anti-inflammatory, anti-malarial, } \\
\end{array}$ & anti-proliferative, anti-viral, immune modulation, nitric oxide \\
& & scavenging activity & \\
6. & Vernonia cinerea & Analgesic, anti-bacterial, anti-inflammatory, anti-pyretic & $33-38$ \\
\hline
\end{tabular}

Jah Hut people often use $V$. cinerea to relief asthma. Asthma is reversible airway obstruction associated with mucosal inflammation caused by mast cells and basophils degranulation resulting in the release of inflammatory mediator. Recent studies revealed the anti-inflammatory activities of $V$. cinerea, ${ }^{[34,35]}$ therefore it is reasonable to use it in relieving asthma.

Other plants, which were not documented in phytopharmacological literatures and of interest may be exploited so that the underlying mechanisms in different diseases of treatment by pharmacological methods can be done. This approach has great significance in discovery of novel pharmacological preparations. For example, Alstonia angustiloba and Homalanthus populneus are used to relieve headache in Jah Hut herbal remedy. Since headache can caused by a wide spectrum of factors, stress, neurological disturbances, infections and so on, it might be interesting to study the underlying mechanisms of these herbs, or pure substances within it, against headache. It may probably possess antidepressant or anti-hypertensive activity. The Physalis minima, Pyrrosia piloselloides and Smilax lanceifolia are often used to relieve pain, it is of practical use to search and extract the substances with analgesic action and study the underlying action by phytochemical, pharmacological and toxicological methods.

In conclusion, this study is important to preserve the knowledge of medicinal plants used by Jah Hut people and also it is of important significance to exploit novel pharmacological agents in various treatments of diseases.

\section{ACKNOWLEDGMENTS}

The author thanks Rev. Anthony Naden for his helps in obtaining information; Dr. E. Soepadmo for plants identification; Dr. Stan Moore for his comments on this article.

\section{REFERENCES}

1. Kulip J. An ethnobotanical survey of medicina and other useful plants of Muruts in Sabah, Malaysia. Telopea 2003;10:81-98.

2. Couillard MA. Tradition in tension: carving in a Jah Hut community. School of Comparative Social Sciences, University Sciences of Malaysia Press; 1980.

3. Ang HH, Lee KL, Kiyoshi M. Eurycoma longifolia Jack enhances sexual motivation in middle-aged male mice. J Basic Clin Physiol Pharmacol 2003;14:301-8.

4. Ang HH, Cheang HS. Effects of Eurycoma longifolia jack on laevator ani muscle in both uncastrated and testosterone-stimulated castrated intact male rats. Arch Pharm Res 2001;24:437-40

5. Ang HH, Ngai TH. Aphrodisiac evaluation in noncopulator male rats after chronic administration of Eurycoma Iongifolia Jack. Fundam Clin Pharmacol 2001;15:265-8.

6. Ang $\mathrm{HH}$, Ikeda $\mathrm{S}$, Gan EK. Evaluation of the potency activity of aphrodisiac in Eurycoma longifolia Jack. Phytother Res 2001;15:435-6.

7. Chan KL, Choo CY, Abdullah NR, Ismail Z. Antiplasmodial studies of Eurycoma Iongifolia Jack using the lactate dehydrogenase assay of Plasmodium falciparum. J Ethnopharmacol 2004;92:223-7.

8. Kuo PC, Damu AG, Lee KH, Wu TS. Cytotoxic and antimalarial constituents from the roots of Eurycoma longifolia. Bioorg Med Chem 2004; 12:537-44.

9. Ang $\mathrm{HH}$, Chan $\mathrm{KL}$, Mak JW. In vitro antimalarial activity of quassinoids from Eurycoma longifolia against Malaysian chloroquine-resistant Plasmodium falciparum isolates. Planta Med 1995;61:177-8.

10. Chan KL, O'Neill MJ, Phillipson JD, Warhurst DC. Plants as sources of antimalarial drugs. Part 3 Eurycoma longifolia. Planta Med 1986. p. 105-7.

11. Kuo PC, Shi LS, Damu AG, Su CR, Huang CH $\mathrm{Ke} \mathrm{CH}$, et al. Cytotoxic and antimalarial betacarboline alkaloids from the roots of Eurycoma Iongifolia. J Nat Prod 2003;66:1324-7.

12. Ang HH, Cheang HS. Studies on the anxiolytic activity of Eurycoma longifolia Jack roots in mice. Jpn J Pharmacol 1999;79:497-500.

13. Adimoelja A. Phytochemicals and the breakthrough of traditional herbs in the management of sexual dysfunctions. Int J Androl 2000;23:82-4.

14. Husen R, Pihie AH, Nallappan M. Screening for antihyperglycaemic activity in several local herbs of Malaysia. J Ethnopharmacol 2004;95:205-8.

15. Kardono LB, Angerhofer CK, Tsauri S, Padmawinata K, Pezzuto JM, Kinghorn AD. Cytotoxic and antimalarial constituents of the roots of Eurycoma Iongifolia. J Nat Prod 1991;54:1360-7.

16. Jiwajinda S, Santisopasri V, Murakami A, Sugiyama $\mathrm{H}$, Gasquet $\mathrm{M}$, Riad $\mathrm{E}$, et al. In vitro anti-tumor promoting and anti-parasitic activities of the quassinoids from Eurycoma longifolia, a medicinal plant in Southeast Asia. J Ethnopharmacol 2002;82:55-8.

17. Ueda JY, Tezuka Y, Banskota AH, Le Tran Q, Tran QK, Harimaya Y, et al. Antiproliferative activity of Vietnamese medicinal plants. Biol Pharm Bull 2002;25:753-60.

18. Wiart C, Mogana S, Khalifah S, Mahan M, Ismail $S$, Buckle M, et al. Antimicrobial screening of plants used for traditional medicine in the state of Perak, Peninsular Malaysia. Fitoterapia 2004;75:68-73.

19. Zhang Z, EISohly HN, Jacob MR, Pasco DS, Walker LA, Clark AM. Natural products inhibiting Candida albicans secreted aspartic proteases from Lycopodium cernuum. J Nat Prod 2002;65:979-85.

20. Sulaiman MR, Somchit MN, Israf DA, Ahmad Z, Moin S. Antinociceptive effect of Melastoma malabathricum ethanolic extract in mice. Fitoterapia 2004;75:667-72.

21. Lohezic-Le Devehat F, Bakhtiar A, Bezivin C, Amoros M, Boustie J. Antiviral and cytotoxic activities of some Indonesian plants. Fitoterapia 2002;73:400-5.

22. Jagetia GC, Baliga MS. The evaluation of nitric oxide scavenging activity of certain Indian medicinal plants in vitro: A preliminary study. $\mathrm{J}$ Med Food 2004;7:343-8.

23. Kamiya $\mathrm{K}$, Tanaka Y, Endang H, Umar M, Satake T. Chemical constituents of Morinda citrifolia fruits inhibit copper-induced low-density lipoprotein oxidation. J Agric Food Chem 2004;52:5843-8. 
24. Wong DK. Are immune responses pivotal to cancer patient's long term survival? Two clinical case-study reports on the effects of Morinda citrifolia (Noni). Hawaii Med J 2004;63:182-4.

25. Furusawa E, Hirazumi A, Story S, Jensen J. Antitumour potential of a polysaccharide-rich substance from the fruit juice of Morinda citrifolia (Noni) on sarcoma 180 ascites tumour in mice. Phytother Res 2003;17:1158-64.

26. Hirazumi A, Furusawa E. An immunomodulatory polysaccharide-rich substance from the fruit juice of Morinda citrifolia (noni) with antitumour activity. Phytother Res 1999;13:380-7.

27. Hirazumi A, Furusawa E, Chou SC, Hokama Y. Anticancer activity of Morinda citrifolia (noni) on intraperitoneally implanted Lewis lung carcinoma in syngeneic mice. Proc West Pharmacol Soc 1994;37:145-6.

28. Wang MY, Su C. Cancer preventive effect of Morinda citrifolia (Noni). Ann NY Acad Sci 2001;952:161-8.

29. Liu G, Bode A, Ma WY, Sang S, Ho CT, Dong Z. Two novel glycosides from the fruits of Morinda citrifolia (noni) inhibit AP-1 transactivation and cell transformation in the mouse epidermal JB6 cell line. Cancer Res 2001;61:5749-56.

30. Wang MY, West BJ, Jensen CJ, Nowicki D, Su C, Palu AK, Anderson G. Morinda citrifolia (Noni): A literature review and recent advances in Noni research. Acta Pharmacol Sin 2002;23:1127-41.

31. Ancolio C, Azas N, Mahiou V, Ollivier E, Di Giorgio C, Keita A, et al. Antimalarial activity of extracts and alkaloids isolated from six plants used in traditional medicine in Mali and Sao Tome. Phytother Res 2002;16:646-9.

32. Younos C, Rolland A, Fleurentin J, Lanhers MC, Misslin R, Mortier F. Analgesic and behavioural effects of Morinda citrifolia. Planta Med 1990;56:430-4.

33. Gupta M, Mazumder UK, Manikandan L, Bhattacharya S, Haldar PK, Roy S. Evaluation of antipyretic potential of Vernonia cinerea extract in rats. Phytother Res 2003;17:804-6.

34. Iwalewa EO, Iwalewa OJ, Adeboye JO. Analgesic, antipyretic, anti-inflammatory effects of methanol, chloroform and ether extracts of Vernonia cinerea less leaf. J Ethnopharmacol 2003;86:229-34.

35. Mazumder UK, Gupta M, Manikandan L, Bhattacharya S, Haldar PK, Roy S. Evaluation of anti-inflammatory activity of Vernonia cinerea Less. Extract in rats. Phytomedicine 2003;10:1858.

36. Latha RM, Geetha T, Varalakshmi P. Effect of Vernonia cinerea Less flower extract in adjuvantinduced arthritis. Gen Pharmacol 1998;31:6016.

37. Kuo YH, Kuo YJ, Yu AS, Wu MD, Ong CW, Yang Kuo LM, et al. Two novel sesquiterpene lactones, cytotoxic vernolide-A and $-B$, from Vernonia cinerea. Chem Pharm Bull 2003;51:425-6.

38. Gupta M, Mazumder UK, Manikandan L, Haldar PK, Bhattacharya S, Kandar CC. Antibacterial activity of Vernonia cinerea. Fitoterapia 2003;74:148-50.

39. Herbal folk wisdom. The sun; 2000. p. 21. 